\title{
MENINGKATKAN KOMPETENSI DASAR FISIKA MELALUI PENERAPAN SIKLUS BELAJAR EXPERIENTIAL PADA SISWA KELAS X SMA NEGERI 3 BAUBAU
}

\author{
Ipedawati \\ Dinas Pendidikan, Pemuda, dan Olahraga Kota Baubau, SMA Negeri 3 Baubau \\ E-mail:waeda.sma3baubau@gmail.com
}

\begin{abstract}
Abstrak
Penelitian ini bertujuan untuk meningkatkan kompetensi dasar fisika siswa kelas X SMA Negeri 3 Baubau dengan menggunakan pembelajaran modul praktikum fisika berbasis kompetensi dengan siklus belajar experential. Penelitian ini adalah penelitian tindakan kelas dengan melibatkan 41 siswa semester II. Penelitian tindakan ini terdiri dua siklus. Data dikumpulkan dengan tes hasil belajar siswa dalam aspek kognitif, tes keterampilan dalam aspek psikomotor, lembar observasi untuk aspek afektif, dan angket untuk respon siswa. Data dianalisis secara kualitatif dan kuantitatif. Hasil penelitian menunjukkan bahwa terjadi peningkatan nilai rata-rata hasil belajar siswa dalam aspek kognitif, afektif dan psikomotor. Terdapat peningkatan aktivitas siswa dalam pembelajaran dengan menggunakan modul praktikum fisika. Hasil analisis terhadap respon siswa menunjukkan bahwa siswa memiliki respon positif terhadap pembelajaran.
\end{abstract}

Kata kunci: modul praktikum experiental, kompetensi dasar fisika.

\begin{abstract}
This study aims to improve the competence of basic physics class X SMA Negeri 3 Baubau using physics-based learning lab module competence by learning cycle experential. This research is a classroom action research involved 41 students the second semester. This action research consisted of two cycles. Data collected by the test results of students in cognitive, psychomotor skills tests in aspect, observation sheet for affective aspect, and a questionnaire for student responses. Data were analyzed qualitatively and quantitatively. The results showed that an increase in the average value of student learning outcomes in the cognitive, affective and psychomotor. There is an increased activity of students in learning by using a physics lab module. The results of the analysis of student responses indicate that students have a positive response to the learning.
\end{abstract}

Keywords: experiential lab module, the basic competencies of physics. 


\section{SANG PENCERAH}

Volume 2, Nomor 1, Agustus 2016, Hlm. 23-33

\section{Ipedawati: Meningkatkan Kompetensi Dasar Fisika Melalui ...}

\section{Pendahuluan}

Pada era globalisasi ini memerlukan SDM yang mampu berkompetisi dalam penguasaan ilmu pengetahuan dan teknologi. Penguasaan ilmu pengetahuan dan teknologi sangat ditentukan oleh penguasaan ilmu sains (fisika). Teknologi tak dapat berkembang tanpa dukungan ilmu sains. Oleh karena itu, penguasaan ilmu sains harus diupayakan melalui peningkatan mutu pendidikan dan pengajaran ilmu sains mulai dari SD sampai perguruan tinggi. Salah satu upaya yang telah dilakukan, diantaranya adalah pemberlakuan kurikulum berbasis kompetensi (KBK) tahun 2004. Dalam kurikulum berbasis kompetensi disebutkan bahwa belajar fisika tidak sekadar belajar informasi fisika tentang fakta, konsep, hukum dalam wujud pengetahuan deklaratif, akan tetapi belajar fisika juga belajar tentang cara memperoleh pengetahuan sains, cara sains dan teknologi (terapan sains) yang bekerja dalam wujud pengetahuan prosedural (prosedural knowledge), termasuk kebiasaan bekerja ilmiah dengan menerapkan metode dan sikap ilmiah (Depdiknas, 2002).

Mengingat kurikulum berbasis kompetensi merupakan hal yang baru, maka dalam pelaksanaan pembelajaran di kelas masih mengalami banyak kendala dari segi teknis maupun non teknis, terbukti masih banyaknya keluhan yang datang dari guru maupun siswa karena pembelajaran yang dicanangkan belum memberikan hasil belajar yang maksimal, seperti yang terjadi di SMA Negeri 3 Baubau, khususnya di kelas X. Walaupun fasilitas pembelajaran dan potensi akademik siswa cukup memadai, tetapi kompetensi dasar fisika dalam aspek kognitif, psikomotor, dan afektif yang dicapai siswa relatif masih rendah, seperti ditunjukkan pada tabel 01 . Rendahnya penguasaan kompetensi dasar fisika yang dicapai siswa merupakan refleksi dari rendahnya kualitas pelaksanaan KBK dalam pembelajaran fisika di SMA Negeri 3 Baubau.

Tabel 1. Profil Kompetensi Siswa SMA Negeri 3 Baubau

\begin{tabular}{clc}
\hline Tahun Ajaran & Aspek Kompetensi & Kelas X \\
\hline $2010 / 2011$ & Kognitif & 51,0 \\
& Psikomotor & 75,0 \\
& Afektif & Cukup \\
\hline $2011 / 2012$ & Kognitif & 57,0 \\
& Psikomotor & 73,0 \\
& Afektif & Cukup \\
\hline
\end{tabular}

Secara umum rendahnya kualitas pelaksanaan KBK dalam pembelajaran fisika bersumber dari kesulitan guru dalam merancang silabus dan skenario pembelajaran yang link dan match dengan indikator pencapaian suatu kompetensi, kebingungan dalam memilih model pembelajaran inovatif yang mendukung pelaksanaan $\mathrm{KBK}$, belum tersedianya model asesmen yang mampu mengevaluasi learning outcome siswa secara menyeluruh, dan kurangnya pemberdayaan sarana dan prasarana yang mendukung pembelajaran berbasis KBK.

Dari hasil survey, observasi dan wawancara pendahuluan terhadap guru/siswa, terdapat beberapa permasalahan pembelajaran fisika berbasis KBK di kelas X SMA Negeri 3 Baubau yang berhasil diidentifikasi sebagai berikut. Pertama, guru belum mengoptimalkan pemberdayaan aktivitas eksperimen dalam kegiatan pembelajaran fisika secara komprehensif dan seimbang. Guru enggan memanfaatkan fasilitas laboratorium yang tersedia untuk menyediakan pengalaman (experience) belajar pada siswa dalam bentuk kegiatan eksperimen (hand/mind-on laboratory) untuk membantu pengkonstruksian kompetensi pada aspek kognitif, psikomotor, dan afektif secara holistik-integeratif pada diri siswa melalui pemberian pengalaman fisika yang bersifat saintifik-akademik. Guru berasumsi bahwa pengalaman fisika dalam bentuk kegiatan eksperimen/demonstrasi akan 


\section{SANG PENCERAH}

Volume 2, Nomor 1, Agustus 2016, Hlm. 23-33

\section{Ipedawati: Meningkatkan Kompetensi Dasar Fisika Melalui ...}

banyak menyita waktu, sehingga pembelajaran fisika terfokus pada penyampaian konsep, prinsip, hukum-hukum yang dapat digunakan untuk menyelesaikan soal ulangan. Kegiatan eksperimen/demonstrasi bersifat insidental saja. Dengan demikian belajar fisika hanya bersifat mekanistik tanpa pernah menyentuh struktur kognitif siswa. Padahal aktivitas siswa dalam mentransformasi pengalaman sainsnya dari prior experience menuju scientific experience memberi kontribusi yang cukup signifikan terhadap pencapaian kompetensi dasar fisika siswa (Kemal Ahmet, 1994). Kedua, guru jarang menggali dan menggunakan pengalaman awal sains siswa (prior experience) sebagai starting point dalam merancang pembelajaran fisika. Kekeliruan siswa dalam melakukan reflective-observation dan memberikan abstract conceptualisation terhadap pengalaman fisika sehari-hari menjadi sumber utama munculnya miskonsepsi, baik pada aspek kognitif, piskomotor, dan afektif (Jeremy Roschele, 1996; Kolb, 1994; Kemal Ahmet, 1994). Bila miskonsepsi ini tidak mendapat penanganan yang baik dan benar, akan menyebabkan miskonsepsi mereka menjadi semakin komplek dan stabil (Ausuble, 1978), yang selanjutnya dapat mengkontaminasi pengkonstruksian kompetensi fisika pada diri siswa secara maksimal. Ketiga, guru kesulitan merancang pembelajaran fisika yang dapat memberikan pengalaman fisika pada siswa secara holistik-integeratif sehingga mendorong terjadinya proses transformasi pengalaman fisika sehari-hari menuju pengalaman fisika saintifik, dan pada akhirnya menjamin pencapaian kompetensi fisika secara optimal. Modul praktikum fisika yang tersedia di sekolah saat ini sebagian besar masih bersifat recipe laboratory yang semata-mata hanya menyediakan pengalaman belajar fisika yang bersifat mekanistik (Colletta, Alfre T \& Chiappetta, Eugene, L. 1994; Hodson, 1990), karena tidak berangkat dari pengalaman nyata (concrete experience), kurang memberi penekanan pada proses reflective observation dan abstract conceptualisation terhadap suatu pengalaman fisika untuk dijadikan dasar dalam menggapai pengalaman fisika baru berikutnya (active experimentation). Keempat, banyak siswa menganggap fisika adalah pelajaran yang sulit dan rumit karena banyak terdapat konsep-konsep, hafalanhafalan, rumus-rumus dan perhitunganperhitungan yang sebagian besar terlepas dari pengalaman sainsnya sehari-hari. Pembelajaran fisika yang hanya menekankan produk sains membuat siswa kurang berminat untuk belajar fisika, sehingga tidak mengherankan aktivitas belajar siswa yang teramati di SMA Negeri 3 Baubau dalam belajar relatif masih sangat rendah. Kelima, berdasarkan wawancara pada beberapa siswa kelas X SMA Negeri 3 Baubau terungkap kesan sebagai berikut, (1) hampir sebanyak $85 \%$ siswa mengungkapkan kurang mendapatkan pengalaman fisika yang dapat digunakan untuk memecahkan persoalan sehari-hari, dan (2) sebanyak 75\% siswa menginginkan pembelajaran fisika yang dapat membangkitkan minat belajar fisika mereka melalui kegiatan fisika yang berkaitan langsung dengan pengalaman sains siswa sehari-hari.

Mengkaji upaya untuk meningkatkan kualitas pembelajaran fisika berbasis KBK di SMA Negeri 3 Baubau, maka salah satu upaya yang tampaknya cukup relevan adalah memberikan suatu tindakan berupa pembelajaran modul praktikum fisika berbasis kompetensi menggunakan siklus belajar experiential sebagai upaya meningkatkan kualitas pelaksanaan KBK dalam pembelajaran fisika. Berdasarkan uraian di atas, fokus penelitian ini adalah bagaiamana meningkatkan kompetensi dasar Fisika melalui penerapan siklus belajar experiental pada siswa kelas X SMA Negeri 3 Baubau.

Tujuan penelitian ini adalah untuk mengetahui efektivitas penerapan siklus 


\section{SANG PENCERAH}

Volume 2, Nomor 1, Agustus 2016, Hlm. 23-33

\section{Ipedawati: Meningkatkan Kompetensi Dasar Fisika Melalui ...}

belajar experiental untuk meningkatkan kompetensi dasar Fisika pada siswa kelas $\mathrm{X}$ SMA Negeri 3 Baubau.

\section{Metode Penelitian}

\section{Desain dan Prosedur Penelitian}

Penelitian tindakan kelas ini dilakukan untuk meningkatkan kompetensi dasar fisika siswa kelas X SMA Negeri 3 Baubau tahun ajaran 2012/2013. Penelitian ini melibatkan 41 orang siswa semester II didasarkan atas masukan dari guru fisika, bahwa (1) semenjak diterapkannya kurikulum berbasis $\mathrm{KBK}$, kompetensi dasar fisika yang biasa dicapai siswa di kelas ini relatif masih rendah, padahal merupakan kelas yang memiliki potensi akademik relatif baik, (2) permintaan guru untuk dibantu dalam merancang pembelajaran fisika yang berbasis KBK guna meningkatkan kualitas pembelajaran fisika. Sebagai obyek penelitian adalah (1) pengalaman awal (prior experience) sains siswa, (2) kualitas pelaksanaan KBK dalam pembelajaran fisika dengan mengimplementasi-kan modul praktikum fisika berbasis kompetensi menggunakan experiential learning model, (3) aktivitas belajar siswa, (4) kompetensi dasar fisika siswa, (5) hambatan-hambatan dalam pembelajaran, dan (6) respon siswa. Penelitian ini merupakan penelitian tindakan kelas yang dirancang atas 2 (dua) siklus selama enam bulan, masing-masing siklus berjalan selama tiga bulan. Dimana setiap siklusnya terdiri atas empat tahapan kegiatan, yaitu (1) Perencanaan, (2) Tindakan, (3) Observasi dan Evaluasi, dan (4) Refleksi yang berulang secara siklis (Tantra, 1997).

Sesuai dengan permasalahan dan tujuan dari penelitian ini, maka data dikumpulkan dengan tes hasil belajar siswa dalam aspek kognitif, tes keterampilan dalam aspek psikomotor, lembar observasi untuk aspek afektif, dan angket untuk respon siswa. Setelah data terkumpul kemudian dianalisis secara kualitatif dan kuantitatif.

Rincian tahapan-tahapan kegiatan yang dilaksanakan pada setiap siklus adalah:

\section{Tahap Perencanaan}

Kegiatan yang dilakukan dalam tahapan perencanaan ini adalah sebagai berikut. (1) Menganalisis dan merumuskan kompetensi yang ingin dicapai, indikator, dan materi sains, selanjutnya menyusun modul praktikum fisika berbasis KBK yang bertolak dari pengalaman awal siswa. (2) Menyiapkan instrumen penelitian yang meliputi, (a) tes penguasaan konsep, (b) pedoman wawancara, (c) tes hasil belajar untuk mengevaluasi penguasaan kognitif, dan (d) pedoman observasi, (e) test uji keterampilan proses sains, (f) pedoman penilaian afektif, dan (g) angket respon siswa. (3) Menyusun perangkat pembelajarannya berupa silabi dan skenario pembelajaran.

\section{Tahap Tindakan}

Prosedur pelaksanaan tindakan secara sederhana ditunjukkan gambar berikut.

Gambar 1. Prosedur pelaksanaan tindakan

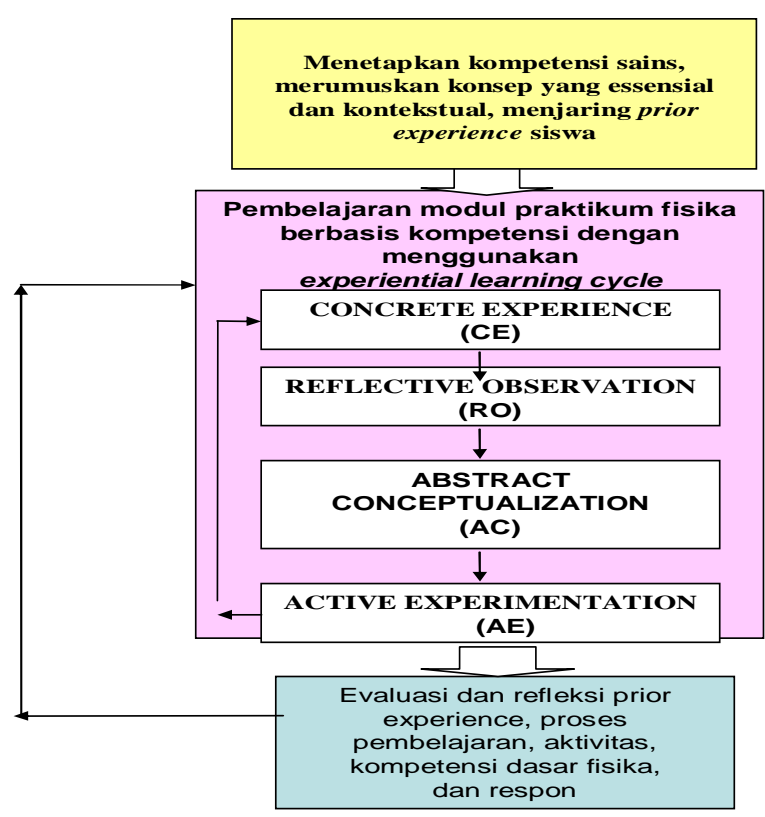




\section{SANG PENCERAH}

Volume 2, Nomor 1, Agustus 2016, Hlm. 23-33

\section{Ipedawati: Meningkatkan Kompetensi Dasar Fisika Melalui ...}

Tahapan-tahapan kegiatan yang dilaksanakan bertolak dari gambar 01 adalah (1) Menyampaikan kepada siswa modul praktikum fisika berbasis kompetensi lebih awal sebelum pembelajaran fisika dimulai. (2) Membentuk kelompok belajar, dimana satu kelompok beranggotakan maksimal 3 orang. (3) Melaksanakan pembelajaran modul praktikum fisika berbasis kompetensi menggunakan experiential learning cycle, dengan tahapan sebagai berikut, menggali dan mengeksplorasi pengalaman awal (prior experience) sisw, (b) berkaitan dengan topik fisika yang akan dibelajarkan, (c) memfokuskan perhatian siswa pada pengalaman sainstifik berupa concrete experience yang telah dicanangkan dalam modul praktikum, (d) dorong dan fasilitasi siswa untuk melakukan observasi dan refleksi secara individual dalam kelompok terhadap pengalaman sains (fisika) tersebut, (e) bimbing dan berdayakan siswa dalam mengabstraksi konseptual pengalaman sains (fisika) yang sedang dieksperimenkan, sampai siswa mampu merumuskan, mengkomunikasasikan, dan memformulasikan secara teoritik pengalaman sains tersebut, dan (f) berikan siswa persoalan sains yang bersifat openended problematik berkaitan dengan pengalaman sains (fisika) yang telah diperoleh dalam kegiatan praktikum, dan dorong siswa untuk mentransformasikan pengalaman tersebut untuk menjelaskan pengalaman sains (fisika) yang lainnya. (4) Melakukan evaluasi terhadap proses dan produk pembelajaran.

\section{Tahap Observasi/Evaluasi}

Observasi/evaluasi dilakukan terhadap beberapa hal sesuai dengan obyek sasaran kegiatan, yakni (1) mengobservasi proses pelaksanaan pembelajaran dengan lembaran observasi; (2) Merekam proses pembelajaran dengan experiential learning cycle menggunakan kamera video; (3) mengevaluasi hasil pembelajaran yang meliputi aspek kognitif, psikomotor dan afektif di akhir masing-masing siklus; (4) mengevaluasi respon siswa dan guru terhadap pembelajaran modul praktikum fisika berbasis kompetensi; dan (5) Menganalisis hasil observasi dan evaluasi untuk dijadikan bahan refleksi pelaksanaan pembelajaran berikutnya.

\section{Tahap Refleksi}

Refleksi dilakukan di akhir setiap siklus. Sebagai dasar refleksi adalah kemasan dan keterbacaan modul praktikum fisika berbasis kompetensi beserta perangkat pembelajarannya, hasil observasi dari proses pembelajaran, hasil evaluasi terhadap penguasaan konsep siswa, tingkat keterampilan proses sains, afektif siswa, dan hasil evaluasi respon siswa terhadap program pembelajaran.

\section{Pembahasan}

\section{Deskripsi Hasil Penelitian Siklus I}

Pada siklus I yang menjadi subyek penelitian adalah siswa kelas X SMA Negeri 3 Baubau tahun ajaran 2012/2013 dengan memberikan mata pelajaran fisika. Materi ajar yang dibelajarkan pada siklus I adalah Kinematika Gerak. Topik praktikum yang dicobakan adalah Gerak Lurus Beraturan. Pembelajaran modul praktikum fisika berbasis kompetensi dengan siklus belajar experiential pada siklus-I nampak bahwa dalam pembelajaran para siswa masih nampak kurang aktif untuk mengikuti pembelajaran. Hanya 1-3 orang siswa dalam kelompok tertentu yang menunjukkan keaktifan. Keadaan kelas masih terpolarisasi antara kelompok yang pintar dengan kelompok yang kurang mampu. Kesalahan ketik, keemasan modul yang kurang menarik, dan keterlambatan dalam pendistribusian ke siswa, cukup menyulitkan siswa mengikuti pembelajaran secara optimal. 


\section{SANG PENCERAH}

Volume 2, Nomor 1, Agustus 2016, Hlm. 23-33

\section{Ipedawati: Meningkatkan Kompetensi Dasar Fisika Melalui ...}

Siswa dalam melakukan praktikum nampak cara kerjanya masih bersifat menunggu informasi dan lebih banyak bertanya, sehingga guru lebih banyak memberikan bimbingan. Siswa kurang aktif dalam melaksanakan eksperimen, dan keterampilan dalam menggunakan alat-alat praktikum yang baru dikenalnya. Eksperimen belum bisa berlangsung sesuai dengan waktu yang dialokasikan, karena peralatan laboratorium sering harus dicari terlebih dahulu, sehingga terlambat untuk menyiapkan peralatan/bahan praktikum, selain itu baik dalam pembelajaran maupun eksperimen intervensi guru sangat dominan dalam memberikan bimbingan, pelatihan, dan bantuan belajar, sehingga belajarnya para siswa bersifat pasif, artinya tidak ada proses internalisasi individualistik pada para siswa melalui kegiatan pengalaman nyata (concrete experience), Proses observasi dan refleksi terhadap pengalamannya (reflective observation), Perolehan hasil refleksi diasimilasi/diakomodasi kedalam struktur kognitif (abstract conseptualisation), dan direformulasi atau dirumuskan hipotesis baru untuk diuji pada situasi baru (active experimentation) dalam konteks interaksi sosial.

Temuan terhadap penguasaan awal siswa menunjukkan bahwa sebelum mengikuti proses pembelajaran, para siswa telah memiliki gagasan tentang topik Gerak dengan kecepatan konstan, dimana mereka menggambarkan tentang kendaraan yang bergerak dengan kecepatan konstan. Dalam gambar tersebut kendaraan bergerak menempuh jarak $100 \mathrm{~m}$ dalam selang waktu 5 second, kemudian dalam selang waktu 5 second berikutnya mobil tersebut tetap menempuh jarak $100 \mathrm{~m}$, dan demikian seterusnya. Gagasan tersebut merupakan kompetensi kognitif mereka yang berasal dari pengetahuan sehari-hari, dan pengetahuan yang diperoleh ketika mereka di SLTP. Sebelum tindakan hampir 6\% siswa memiliki kompetensi dasar fisika terhadap materi ajar Kinematika Gerak. Paling besar para siswa belum memiliki kompetensi yang memadai terjadi pada Benda bergerak dengan laju tetap dan dengan laju berubah sebesar 96\%. Kompetensi siswa bahwa pada benda bergerak dengan laju tersebut dengan selang waktu yang sama dapat menempuh jarak yang sama, semestinya laju benda tersebut berubah-ubah. Namun setelah pembelajaran terjadi penurunan para siswa yang kurang memadai kompetensinya. Hampir 78\% siswa sudah memiliki kompetensi dasar fisika tentang Kinematika Gerak. Demikian juga keterampilannya yang dilakukan dengan cara praktikum mengunakan modul tentang Gerak lurus beraturan yang merupakan materi ajar Kinematika Gerak awal yang dimiliki siswa sebagian besar menunjukkan bahwa siswa kurang terampil dalam menggunakan alat ukur seperti mikrometer, jangka sorong, stop watch, serta dalam mengkonversi Besaran dan satuan.

Hasil analisis perubahan yang sudah memiliki kompetensi dasar fisika yang memadai dari siswa pada siklus I menunjukkan bahwa sebelum pembelajaran rerata persentase siswa yang memiliki kompetensi dasar fisika sebesar 7,2\%, sedangkan yang belum memiliki kompetensi dasar fisika sebesar 92,8\%. Namun setelah pembelajaran rerata persentase siswa yang memiliki kompetensi dasar fisika meningkat menjadi $71,8 \%$, sedangkan siswa yang belum memiliki kompetensi dasar fisika tinggal $28,2 \%$. Terjadi penurunan rerata persentase siswa yang belum memiliki kompetensi dasar fisika sebesar $64,6 \%$. Hal ini berarti bahwa penerapan modul praktikum fisika berbasis kompetensi dengan siklus belajar Experiential mampu menurunkan yang belum memiliki kompetensi dasar fisika para siswa. Meskipun harus diakui bahwa pada siklus I ini yang belum memiliki kompetensi dasar fisika bagi siswa belum dapat dientaskan. Masih ada rata-rata 28,2\% 


\section{SANG PENCERAH}

Volume 2, Nomor 1, Agustus 2016, Hlm. 23-33

\section{Ipedawati: Meningkatkan Kompetensi Dasar Fisika Melalui ...}

siswa yang masih belum memiliki kompetensi dasar fisika yang memadai.

Selanjutnya pada siklus I hasil belajar yang diperoleh siswa dari aspek kognitif adalah 70,21 dengan simpangan baku 15,4. Hasil observasi terhadap para siswa tersebut yang diperoleh dari aspek afektif adalah 74,40 termasuk kategori cukup. Rata-rata keterampilan psikomotor sebesar 68,46 dengan SD 3,29. Hal ini berarti kualitas hasil belajar siswa relatif masih rendah, demikian juga penguasaan sainstifiknya. Secara keseluruhan hasil yang diperoleh pada siklus I seperti ditunjukkan pada gambar 2 . Relatif rendahnya hasil belajar yang diperoleh siswa dalam pembelajaran fisika sebagian bersumber dari rendahnya penguasaan konsep atau kurang memiliki kompetensi dasar fisika dengan baik, tidak memiliki kemampuan analisis yang baik dan akibat kesalahan teknis-matematis. Siswa dalam mengikuti pembelajaran dan praktikum belum mempersiapkan diri secara baik dengan membaca modul dan petunjuk praktikum. Hal ini terlihat dari rendahnya partisipasi siswa dalam pembelajaran, dan masih dominannya guru memberikan bimbingan, pelatihan, dan bantuan belajar dalam penanaman kompetensi dasar fisika dan atau keterampilan praktikum fisika di laboratorium. Nilai rata-rata aktivitas siswa pada siklus I adalah 63 termasuk kategori cukup aktif.

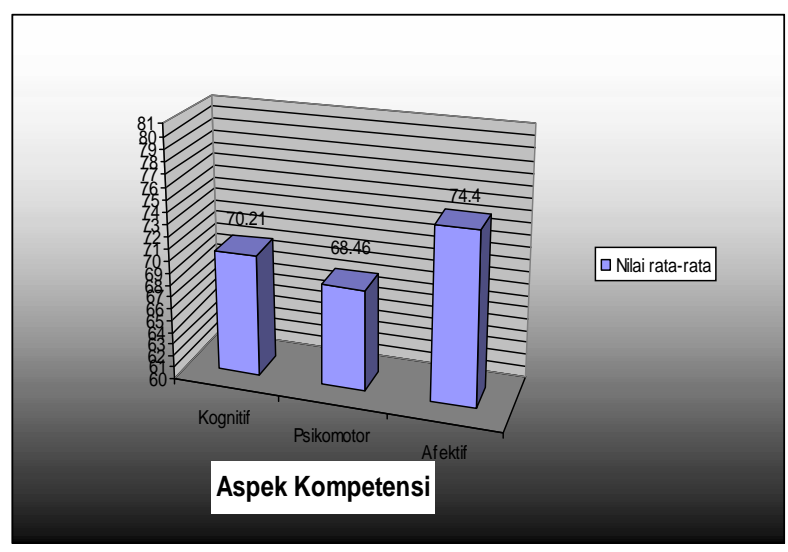

Gambar 2. Hasil penelitian pada siklus I

\section{Deskripsi Hasil Penelitian Siklus II}

Materi ajar yang disampaikan pada pembelajaran pada siklus II adalah Dinamika partikel. Topik praktikum yang dicobakan adalah mengamati sifat kelembaman, pengaruh gaya pada percepatan ,dan pengaruh massa pada percepatan. Dengan penyempurnaan modul dan pendistribusian ke para siswa lebih awal, ditemukan beberapa kemajuan dalam pelaksanaan pembelajaran dan praktikum seperti para siswa sudah mulai aktif dalam merespon pertanyaan guru dalam diskusi, disinilah tahap concrete experience terjadi, sedang pada tahap reflektif observation ini dimana pebelajar mengamati secara seksama pengalaman dari aktifitas sains yang sedang dilakukan dengan menggunakan panca indera (sense) juga perasaan (feeling) atau alat bantu laboratorium lainnya, selanjutnya merefleksikan pengalaman dan menarik pelajaran dari pengalaman tersebut berdasarkan hasil refleksi. Proses tersebut terjadi karena adanya dorongan dari guru pada pebelajar sehingga mampu mendeskripsikan pengalaman yang telah diperolehnya, serta mengkomunikasikannya pada teman-temannya. Dengan demikian terbangkitkan gairah belajar para siswa, aktivitas belajar para siswa dalam pembelajaran dan praktikum mulai meningkat karena adanya kemandirian dari para siswa dalam pelaksanaan pembelajaran maupun praktikum, pebelajarpun sudah mampu mempersiapkan, mensetting, dan mengoperasikannya sendiri dengan tingkat bimbingan relatif lebih rendah. Nilai ratarata aktivitas siswa pada siklus II adalah 72 termasuk kategori aktif.

Pada siklus II ini juga ditemukan adanya peningkatan kompetensi dasar fisika para siswa. Sebelum tindakan $96 \%$ siswa masih belum memiliki kompetensi dasar fisika tentang sifat kelembaman dalam kehidupan sehari-hari, hanya $4 \%$ siswa yang mengerti secara seksama berdasarkan pengalaman yang dialaminya, sehingga 


\section{SANG PENCERAH}

Volume 2, Nomor 1, Agustus 2016, Hlm. 23-33

\section{Ipedawati: Meningkatkan Kompetensi Dasar Fisika Melalui ...}

mereka mampu mendeskripsikan pengalamannya serta mengkomunikasikan pada teman-temannya. Sedangkan pada tahap Abstrak conceptualisation yang merupakan fase think, dimana pebelajar mau mencermati reasoning, hubungan timbalbalik (reciprocal-causing) terhadap pengalaman (experience) yang diperoleh setelah melakukan observasi dan refleksi terhadap pengalaman sains pada fase concrete experience masih sangat rendah persentasenya dilihat dari data tersebut di atas. Namun setelah tindakan pembelajaran terjadi peningkatan kompetensi dasar fisika. Sebanyak hampir $85 \%$ siswa sudah memiliki kompetensi dasar fisika tentang sifat kelembaman dalam kehidupan sehari-hari dimana mereka dapat menjelaskan apa yang dirasakannya pada saat naik kendaraan. Jika kendaraan dalam keadaan diam, kemudian tiba-tiba bergerak maka tubuh mereka akan terdorong ke belakang.

Mengapa hal tersebut dapat terjadi? Setelah dilakukan observasi dengan kendaraan salah seorang guru pengajar di SMA Negeri 3 dan dinaiki oleh sekitar 7 orang siswa dan seorang supir maka diperoleh penyebabnya yang dirasakan para siswa tersebut adalah bahwa tubuh mereka ingin mempertahankan keadaannya semula yaitu ingin tetap diam. Demikian pula jika kendaraan sedang melaju, kemudian direm secara tiba-tiba maka tubuh mereka terasa ingin mempertahankan keadaannya semula yaitu ingin tetap bergerak. Setelah observasi dengan pengalamannya tersebut mereka telah bertambah tahapan siklus belajar experiential nya dengan tahap active experimentation, dimana pebelajar mencoba merencanakan bagaimana menguji keampuhan teori untuk menjelaskan pengalaman baru yang akan diperoleh selanjutnya, disinilah telah terjadi proses belajar bermakna pada tahap ini dimana pengalaman yang diperoleh sebelumnya dapat diterapkan pada pengalaman baru dan atau situasi problematik yang baru.
Hasil analisis perubahan yang sudah memiliki kompetensi dasar fisika yang memadai dari siswa pada siklus II menunjukkan bahwa sebelum pembelajaran rerata persentase siswa yang memiliki kompetensi dasar fisika sebesar 12,6\%, sedangkan yang belum memiliki kompetensi dasar fisika 87,4\%. Namun setelah pembelajaran rerata siswa yang memiliki kompertensi dasar fisika meningkat menjadi $81,4 \%$, sedangkan yang masih belum memiliki kompetensi dasar fisika tersisa 18,6\%. Maka terjadi peningkatan rerata persentase siswa yang sudah memiliki kemampuan kompetensi dasar fisika sebesar 68,8 atau penurunan yang belum memiliki kompetensi dasar fisika sebesar 4,7\%. Pada siklus II ini juga belum mampu mengentaskan yang belum memiliki kompetensi dasar secara keseluruhan, karena masih ada siswa yang belum memiliki kompetensi dasar fisika yang bersifat resisten sebesar rata-rata $18,5 \%$.

Selanjutnya pada siklus II hasil belajar yang diperoleh siswa dari aspek kognitif adalah 74,68 dengan simpangan baku 12,84. Hasil observasi terhadap para siswa tersebut yang diperoleh dari aspek afektif adalah 80,70 termasuk kategori baik. Rata-rata keterampilan psikomotor sebesar 75,36 dengan simpangan baku 5,67. Hal ini berarti kualitas hasil belajar siswa relatif lebih baik dibandingkan pada siklus I, demikian juga penguasaan sainstifiknya. Secara keseluruhan hasil yang diperoleh pada siklus II seperti ditunjukkan pada gambar dibawah ini. Data tersebut menunjukkan adanya peningkatan hasil belajar yang diperoleh siswa dalam pembelajaran fisika sebagian bersumber dari lebih baiknya penguasaan konsep atau telah memiliki kompetensi dasar fisika dengan baik, sudah memiliki kemampuan analisis yang baik dalam keterampilan memecahkan soal-soal. Siswa dalam mengikuti pembelajaran dan praktikum sudah mempersiapkan diri secara baik dengan membaca modul dan petunjuk 


\section{SANG PENCERAH}

Volume 2, Nomor 1, Agustus 2016, Hlm. 23-33

\section{Ipedawati: Meningkatkan Kompetensi Dasar Fisika Melalui ...}

praktikum. Hal ini terlihat dari adanya peningkatan yang lebih baik dalam hal partisipasi siswa dalam pembelajaran, dan sudah jauh berkurang dominasi guru memberikan bimbingan, pelatihan dan bantuan belajar dalam penanaman kompetensi dasar fisika dan atau keterampilan praktikum fisika di laboratorium. Hasil penelitian pada siklus II ditunjukkan pada gambar berikut.

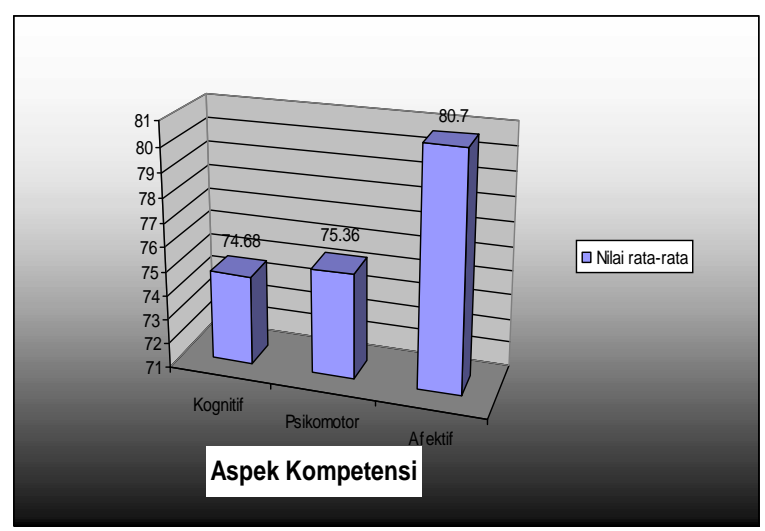

Gambar 3. Hasil Penelitian pada Siklus II

Peningkatan hasil belajar fisika siswa dalam pembelajaran menggunakan siklus belajar experiential menunjukkan signifikansinya, hal ini ditunjukkan dengan pencapaian nilai tinggi/baik sebesar $60 \%$, nilai sedang/cukup sebesar $40 \%$, dan tidak ada siswa yang memperoleh nilai rendah/kurang.

Analisis terhadap hasil distribusi respon siswa seperti terlampir. Sebanyak $25 \%$ siswa memiliki persepsi yang sangat positif terhadap modul, petunjuk praktikum dan proses pembelajaran, 40,5\% memiliki persepsi positip, 23,6\% cukup positif, 9,2\% negatif dan $1,7 \%$ memiliki persepsi sangat negatif. Dari data ini jumlah persentase siswa yang memiliki persepsi dan sikap sangat positif dan positif adalah $65,5 \%$ sedangkan jumlah siswa yang berpersepsi negatif dan sangat negatif adalah 20,7\%.

Dari hasil observasi dan rekaman video tentang aktivitas siswa dalam pembelajaran dan praktikum terlihat adanya kemandirian siswa dalam mengikuti pembelajaran dan praktikum fisika. Keemasan modul yang mudah dicerna dan dipahami, serta pendistribusian modul lebih awal dengan membaca isi modul fisika lebih dahulu, sehingga interaksi pembelajaran berlangsung lebih baik, dimana sebagian besar siswa aktif dalam merespon pertanyaan guru, bahkan banyak siswa mampu memposisikan diri sebagai mentor pengimbas bagi temannya, baik dalam pembelajaran teori maupun dalam pelaksanaan praktikum.

\section{Uraian Hasil Siklus 1 dan 2}

Hasil belajar siswa dalam aspek kognitif yang berkaitan dengan konsep kinematika dan dinamika partikel ditunjukkan dengan nilai rata-rata. Pada siklus I nilai rata-rata hasil belajar siswa dalam aspek kognitif adalah 70,21 termasuk kategori cukup, sedangkan pada siklus II nilai rata-rata siswa adalah 74,68 termasuk kategori baik. Hasil belajar siswa dalam aspek afektif ditunjukkan dengan nilai ratarata. Pada siklus I nilai rata-rata hasil belajar siswa dalam aspek afektif adalah 74,40 termasuk kategori cukup, sedangkan pada siklus II nilai rata-rata siswa adalah 80,70 termasuk kategori baik. Hasil belajar siswa dalam aspek psikomotor ditunjukkan dengan nilai rata-rata. Pada siklus I nilai rata-rata hasil belajar siswa dalam aspek psikomotor adalah 68,46 termasuk kategori cukup, sedangkan pada siklus II nilai ratarata siswa adalah 75,36 termasuk kategori baik.

Berdasarkan pelaksanaan pembelajaran yang telah dilakukan dalam penelitian ini, bahwa dengan penerapan pembelajaran modul praktikum fisika berbasis kompetensi dengan siklus belajar experiential dalam upaya meningkatkan kompetensi dasar fisika siswa kelas X SMA Negeri 3 Baubau telah mampu meningkatkan kompetensi 


\section{SANG PENCERAH}

Volume 2, Nomor 1, Agustus 2016, Hlm. 23-33

\section{Ipedawati: Meningkatkan Kompetensi Dasar Fisika Melalui ...}

dasar fisika siswa menjadi scientific experience. Hal ini ditunjukkan dengan hasil belajar fisika siswa menunjukkan peningkatan pencapaian nilai tinggi/baik sebesar $60 \%$, nilai sedang/cukup $40 \%$, dan tidak ada siswa yang memperoleh nilai rendah/kurang.

Berdasarkan kriteria yang ditetapkan yakni untuk semua aspek kompetensi dasar fisika nilai rata-rata siswa berkategori baik, maka pembelajaran modul praktikum fisika berbasis kompetensi dengan siklus belajar experiential telah dapat memberikan kesempatan kepada siswa untuk mengkonstruksi pengetahuan sendiri dan memberikan kesempatan kepada siswa untuk mengaitkan konsep-konsep yang sudah dipahami dengan konsep-konsep yang akan dipelajari sehingga terjadi proses belajar bermakna dan model pembelajaran experiential dapat menjadikan pengalaman berharga bagi siswa dalam hal mengemukakan gagasan yang sudah mereka miliki dan menguji serta mendiskusikan gagasan tersebut secara terbuka. Hal ini akan membantu siswa untuk membangun konsep secara konstruktif, sehingga dapat mengurangi miskonsepsi pada diri siswa dan meningkatkan konsepsi ilmiah, yang pada akhirnya akan memberikan kontribusi pada peningkatan hasil belajar siswa.

Dari hasil observasi dan rekaman video jelas nampak bahwa pembelajaran modul praktikum fisika berbasis kompeteni dengan siklus belajar experiential dapat menciptakan kondisi pembelajaran yang kondusif bagi siswa. Sebelum pembelajaran pada diri siswa sebenarnya sudah terjadi konflik kognitif antara konsepsi awal yang dibawanya dengan konsep ilmiah yang terdapat dalam modul. Proses negoisasi dan deregulasi terjadi dalam pembelajaran melalui tahap siklus belajar experiential dimulai dari concrete experience, reflective observation, abstract conceptualization, dan active experimetation. Proses negoisasi dan deregulasi akan berhasil bila pebelajar (siswa) mau melakukan (1) berpartisipasi dalam suatu aktivitas, (2) menyelidiki secara kritis aktivitas pengalaman untuk diklarifikasi, (3) menarik pemahaman yang berguna dari analisis terhadap pengalaman yang diperoleh, dan (4) menggunakan pengalaman yang telah diperoleh untuk bekerja pada situasi atau pengalaman yang baru.

Peningkatan kompetensi dasar fisika secara ilmiah akan memberikan kontribusi pada peningkatan kemampuan siswa untuk memecahkan persoalan-persoalan fisika secara teoritik dalam pembelajaran maupun praktik dalam kegiatan eksperimen, sehingga hasil belajar fisika yang diperoleh siswa relatif lebih baik. Tahapan pembelajaran modul praktikum fisika berbasis kompetensi dengan siklus belajar experiential telah memberikan kesempatan kepada siswa untuk menguasai kompetensi dasar fisika secara berjenjang dan sistematis mulai dari tahap concrete experience, reflective observation, abstract conseptualization, dan active experimentation, sehingga siswa dapat terbimbing dengan baik menuju penguasan konsep dan keterampilan fisika berangkat dari kompetensi dasar fisika awalnya.

Temuan tentang aktivitas siswa dalam pembelajaran mengalami peningkatan dari siklus I ke siklus II. Pada siklus I nilai ratarata aktivitas siswa adalah 63 termasuk dalam kategori cukup aktif, sedangkan pada siklus II nilai rata-rata aktivitas siswa adalah 72 dalam kategori aktif. Ini berarti bahwa siklus belajar experiential dapat meningkatkan aktifitas siswa dalam pembelajaran dengan menggunakan modul praktikum fisika berbasis kompetensi, sehingga kompetensi dasar fisika siswa dapat meningkatkan hasil belajarnya dan siswa diberikan kesempatan untuk bekerja seperti ilmuwan, sehingga rasa ingin tahu siswa semakin berkembang dan memberikan kesempatan kepada siswa untuk menggunakan keterampilan proses 


\section{SANG PENCERAH}

Volume 2, Nomor 1, Agustus 2016, Hlm. 23-33

\section{Ipedawati: Meningkatkan Kompetensi Dasar Fisika Melalui ...}

IPA, dengan kata lain melalui siklus belajar experiential pembelajaran berpusat pada siswa.

\section{Simpulan}

Hasil analisis respon siswa terhadap siklus belajar experiental menunjukkan bahwa sebanyak $25 \%$ siswa memiliki persepsi yang sangat positif terhadap modul, petunjuk praktikum dan proses pembelajaran, $40,5 \%$ memiliki persepsi positif, $23 \%$ cukup positif, $9,2 \%$ negatif dan $1,7 \%$ memiliki persepsi sangat negatif. Dari data tersebut jumlah persentase siswa yang memiliki persepsi dan sikap sangat positif dan positif adalah $65,5 \%$, sedangkan jumlah siswa yang berpersepsi negatif dan sangat negatif adalah $20,7 \%$.

\section{Daftar Pustaka}

Atherton, J.S. 2002. Learning and Teaching: Learning from Experience, http://www.dmu.ac.uk/ jamesa/learning/experinece.html.

Ausuble. 1978. Educational Pshycology: A Cognitive View $2^{\text {nd }}$. New York, Holt Rinerhart and Winstone.

Boud, D. 1985. Reflection. Turning Experience into Learning. London: Kogan Page.

Curtis Kelly, 1997, David Kolb, The Theory of Experiential Learning and ESL. The Internet TESL Journal, Vol. III, No 9.

Depdiknas. 2002. Kurikulum Berbasis Kompetensi Mata Pelajaran Sains. Jakarata: Puskur.

Henry, J. 1989. Meaning and Practice in Experiential Learning. In Making Sense of Experiential Learning: Diversity in Theory and Practice, eds. S. Warner Weil and Mc.Gill. The Society for Research into
Higher Education \& Open University Press.

Kemal, Ahmet. 1994. An Experiential Approach to Science Teaching for Students of Construction. Park Square Luton. University of Luton

Kolb, D.A. 1994. Experiential Learning: Experience as the Source of Learning and Development. Englewood Cliffs, New Jersey: PrenticeHall.

Kolb, D.A, \& Richard, E. 1999. Experiential Learning Theory: Previous Research and New Direction. Department of Organizational Behaviour Weatherhead School of Management Case Western Reserve University.

Luickman, C. 1996. Defining Experiential Education. The Journal of Experiential Education, 19(1) pp 6-7.

Mellor, A. 1991. Experiential Learning Through Integrated Project Work: An Example from oil Science. Journal of Deography in Higher Education 15(2): 135-149.

Nadine Ryan Bannerman. 2003. Facilitating Powerfull Learning Experineces: Experiential Learning $\mathcal{E}$ the Experiential Learning Cycle. Ryan-Bannerman Assosiates. www. ryanbannerman.com.

Tantra, D.K. 1997. Penelitian Tindakan, Konsep Dasar dan Pelaksanaannya. Pusat Penelitian dan Pengabdian pada Masyarakat (P3M) STKIP Singaraja.

Tonny Sadington. 2004. What is Experiential Learning. Article. Centre for Higher Education Development. University of Capetown.

Travers, N. 1998. Experiential Learning and Students' Self-regulation. Saratoga Spring, NY: The National Centre on Adult Learning. 